\title{
Simulation method of operating parameters assessment used for engine comparative analysis
}

\begin{abstract}
The methodology of engine operating parameters assessment that could be used for comparative tests has been presented in the paper. The basic assumption is that the engine is tested during free acceleration. Another assumption of the presented method is that the relative change of parameter could be assessed on the basis of values which are close to exact parameter values. All these parameters are both measured with the same accuracy and under the same conditions. The accuracy of the model has been identified for S-4002 engine. The sample test results have been presented.
\end{abstract}

Key words: combustion engine, transient conditions, speed characteristics, engine test

\section{Symulacyjna metoda określania parametrów roboczych do analiz porównawczych silnika}

\begin{abstract}
$W$ artykule przedstawiono metodykę określania parametrów roboczych silnika przydatnych do badań porównawczych. Podstawowymi założeniami proponowanej symulacyjnej metody określania parametrów są: 1) silnik powinien być badany na biegu luzem podczas gwaltownego rozpędzania, 2) zmiana względna parametru może być oszacowana na podstawie wartości zbliżonych do poziomu wartości bezwzględnych, mierzonych z ta sama dokładnościa $i w$ takich samych warunkach pomiaru. Przedstawiono przykładowe wyniki przeprowadzonych testów.
\end{abstract}

Słowa kluczowe: silnik spalinowy, warunki nieustalone, charakterystyka, test silnika

\section{Introduction}

It is well known that the real data obtained from a sure source such as experimental tests are the most useful for analysis. The measurements on the test bed are the most appropriate for combustion engines. But it very often happens that the use of test bed measurements for the case of engine simple modification is too expensive, work and time consuming. This situation is characteristic of engine tuning.

The modification is usually time efficient because it concerns only the exchange of the ECU controller or a unit exchange or simply the resetting of the parameters. The changes are often introduced step by step and then optimal settings are sought. In this situation test bed usage which is much more time consuming, significantly encumbers the execution of all the procedures. Especially when the engine is fitted into the vehicle.

One of the solutions is the use of chassis dynamometer for running check of the engine operating parameter changes during the modification process. But some restrictions appear that are connected to additional losses in transmissions and decrease in measurement accuracy. The main problem is the necessity of stabilization of the thermal state of transmission units which influences the quantity of losses.

The different technique of operating parameters measurement could also be proposed. It is based on inertial method measurements.

\section{Method assumptions}

The basic assumption of the simulation method of engine operating parameters assessment is that the engine is tested under specific conditions i.e. during free acceleration. The second assumption of the presented method is that a rela-

\section{Wstęp}

W pracach z zakresu analizy porównawczej najbezpieczniej jest wykorzystywać dane rzeczywiste, pochodzące $z$ pewnego źródła, czyli z pomiarów eksperymentalnych. W przypadku silników spalinowych najbardziej właściwe są pomiary na hamowni silnikowej. Jednak często zdarza się, że przeprowadzenie pomiarów hamownianych jest zbyt kosztowne lub czasochłonne, aby je zastosować do analizy porównawczej jakiegoś prostego przypadku modyfikacji silnika. Sytuacja taka jest charakterystyczna dla tzw. tuningu silnika. Dokonywana modyfikacja jest zwykle mało czasochłonna, gdyż polega np. na wymianie sterownika, przeregulowaniu lub wymianie podzespołu. Często zmiany wprowadza się etapami, szukając ustawienia optymalnego. Zatem badanie hamowniane, które jest bardziej czasochłonne, utrudnia przeprowadzenie całej procedury, szczególnie, jeżeli silnik jest zamontowany w pojeździe.

Pewnego rodzaju rozwiązaniem jest stosowanie hamowni podwoziowej do bieżącej kontroli zmian parametrów roboczych silnika podczas procesu modyfikacji. Jednak występują tu ograniczenia związane z dodatkowymi stratami energii w układzie napędowym i zmniejszeniem dokładności pomiaru. Ważnym problemem jest także utrzymanie właściwego stanu cieplnego podzespołów przenoszących napęd, co ma wpływ na wielkość wspomnianych strat.

Można także zaproponować inny sposób pomiaru parametrów roboczych silnika, oparty na inercyjnej metodzie pomiaru.

\section{Założenia metody}

Podstawowym założeniem symulacyjnej metody określania parametrów roboczych silnika do celów porównaw- 
tive change of a parameter could be assessed on the basis of values which are close to the exact parameter values. All these parameters are both measured with the same accuracy and under the same conditions.

\section{Test conditions in inertial method}

Engine operating parameters measurement is executed during free acceleration which is caused by full throttle without any external load. Unloaded engine obtaining the largest fuel dose uses energy surplus for the increase of kinetic energy of its movable masses. This may be presented by the following equations.

The engine operation during crankshaft speed change in the whole case shown as:

$$
\mathrm{J}_{\mathrm{z}} \cdot \frac{\mathrm{d} \omega}{\mathrm{dt}}=\mathrm{T}_{\mathrm{e}}-\mathrm{T}_{\mathrm{op}} \quad \frac{\mathrm{d} \omega}{\mathrm{dt}} \neq 0
$$

where: $T_{e}$ - running engine torque, $T_{o p}$ - external resistance torque including receiver inertia, $\mathrm{J}_{\mathrm{z}}$ - equivalent mass moment of inertia of mobile engine elements in relation to crankshaft axis, $\omega$ - engine angular speed, $\mathrm{t}$ - time.

If engine operates without an external receiver connected, that external resistance torque will not appear $\left(\mathrm{T}_{\mathrm{op}}=0\right)$, and equation (1) will be transformed into Eq. (2),

$$
\mathrm{T}_{\mathrm{e}}=\mathrm{J}_{\mathrm{z}} \cdot \frac{\mathrm{d} \omega}{\mathrm{dt}}=\mathrm{J}_{\mathrm{z}} \cdot \varepsilon
$$

where: $\varepsilon$ - angular acceleration of engine crankshaft.

From equation (2) it results that the effective engine torque is proportional to the angular acceleration of the engine crankshaft in these conditions. So the measurement of the crankshaft angular acceleration makes the assessment of the engine torque possible.

It should be emphasized that the value of the equivalent mass moment of inertia $\mathrm{J}_{\mathrm{z}}$ is essential. If the value of the equivalent mass moment of inertia of the engine in actual configuration is known then the calculation of the exact values of the tested engine torque and power is possible. But if this value is unknown then the simulation method of parameter assessment could be used.

\section{Methodology of comparison parameters determination}

The valuation of the engine parameters changes may be fundamentally based only on angular acceleration values that are measured with a relatively high level of precision. But in practice the most of the users prefer obtaining the engine torque and the power values. Then the problem of recalculating of the measurement results to variables as torque and power appears.

\subsection{Measurement experiment}

The course of crankshaft angular acceleration of the tested engine is obtained as a result of measurement experiment. This is the function $\varepsilon=\mathrm{f}(\mathrm{n})$ from the speed characteristics family. The determining of the engine torque and power courses needs angular acceleration to be recalculated with the Eq. (2) and (3), czych jest to, aby badany silnik był na biegu luzem, ale w szczególnych warunkach pracy, tj. podczas gwałtownego rozpędzania.

Drugim założeniem jest to, że do określenia zmiany parametru nie jest konieczna znajomość dokładnej wartości bezwzględnej parametru. Zmiana względna parametru może być oszacowana na podstawie wartości zbliżonych do poziomu wartości bezwzględnych, mierzonych z tą samą dokładnością i w takich samych warunkach pomiaru.

\section{Warunki pomiaru w metodzie inercyjnej}

Pomiar parametrów roboczych silnika następuje podczas szybkiego rozpędzania silnika, powodowanego pełnym wysterowaniem układu zasilania podczas pracy na biegu luzem [2]. Nieobciążony silnik, otrzymując pełną dawkę paliwa zużywa nadwyżkę wytwarzanej energii na zwiększenie energii kinetycznej swoich mas ruchomych, co przedstawiono za pomocą równań.

Działanie silnika podczas zmiany prędkości obrotowej wału korbowego w ogólnym przypadku może być opisane jako (1),

gdzie: $\mathrm{T}_{\mathrm{e}}$ - bieżący moment obrotowy silnika, $\mathrm{T}_{\mathrm{op}}$ - moment oporów zewnętrznych, zawierający bezwładność odbiornika, $\mathrm{J}_{z}$ - zastępczy masowy moment bezwładności ruchomych elementów silnika zredukowany do osi wału korbowego, $\omega$ - prędkość kątowa wału silnika, $\mathrm{t}$ - czas.

Jeżeli silnik działa bez dołączonego odbiornika zewnętrznego, to wtedy nie wystąpi moment oporów zewnętrznych $\left(\mathrm{T}_{\mathrm{op}}=0\right)$, zatem równanie (1) przyjmie postać (2), gdzie: $\varepsilon$-przyspieszenie kątowe wału korbowego.

Z zależności (2) wynika, że efektywny moment obrotowy silnika jest $\mathrm{w}$ tych warunkach proporcjonalny do przyspieszenia kątowego wału korbowego silnika. Zatem mierząc przyspieszenia kątowe, można mówić o efektywnym momencie obrotowym silnika.

Należy zauważyć, że zasadniczą rolę pełni tu wartość zastępczego masowego moment bezwładności ruchomych elementów silnika $\mathrm{J}_{z}$. Jeżeli znana jest dokładna wartość masowego momentu bezwładności silnika w danej konfiguracji, wtedy możliwe jest wyliczenie dokładnych wartości bezwzględnych mocy i momentu obrotowego badanego silnika. Natomiast, gdy ta wartość nie jest znana, można zastosować symulacyjną metodę wyznaczania parametrów, proponowaną w niniejszym artykule.

\section{Metodyka wyznaczania parametrów porównawczych}

Do oceny zmiany parametrów silnika można by uwzględnić wartości samego przyspieszenia kątowego, które jest mierzone dość dokładnie [4]. Jednak w praktyce preferuje się wartości mocy i momentu obrotowego silnika. Pojawia się zatem konieczność przeliczania uzyskiwanych wyników pomiaru na moc i moment obrotowy.

\subsection{Eksperyment pomiarowy}

W wyniku eksperymentu pomiarowego metodą inercyjną uzyskuje się przebieg przyspieszeń kątowych wału korbowego badanego silnika. Jest to funkcja $\varepsilon=\mathrm{f}(\mathrm{n})$ postaci charak- 


$$
\begin{gathered}
\mathrm{T}_{\mathrm{e}}=2 \cdot \pi \cdot \mathrm{J}_{\mathrm{z}} \cdot \varepsilon \\
\mathrm{N}_{\mathrm{e}}=10^{-3} \cdot \frac{\pi^{2}}{15} \cdot \mathrm{J}_{\mathrm{z}} \cdot \varepsilon \cdot \mathrm{n}
\end{gathered}
$$

where: $\mathrm{T}_{\mathrm{e}}$ - engine effective torque in $\mathrm{N} \cdot \mathrm{m}, \mathrm{N}_{\mathrm{e}}$ - engine effective power in $\mathrm{kW}, \mathrm{J}_{\mathrm{z}}$ - equivalent mass moment of inertia in $\mathrm{kgm}^{2}, \varepsilon$-angular acceleration of engine crankshaft in $1 / \mathrm{s}^{2}$, $\mathrm{n}$ - engine speed in rpm.

The realization of these recalculations enables to chart the torque and power speed characteristics obtained under transient condition and the assessment of the effectiveness of the introduced changes in the engine.

\subsection{Basic characteristic determination}

The formulas (3) and (4) show that the value of the equivalent mass moment of inertia $\mathrm{J}_{\mathrm{z}}$ is fundamental for the calculating process of torque and power. In practice it is possible to obtain different values of torque and power for this same value of measured angular acceleration using the $\mathrm{J}_{\mathrm{z}}$ parameter.

In the graph $\mathrm{T}-\mathrm{n}$ the course $\mathrm{T}_{\mathrm{e}}=\mathrm{f}(\mathrm{n})$ obtained from a good source, for example catalogue data, is inserted. Next the course $T_{e}^{\varepsilon}=f(n)$ calculated from the measured values of angular acceleration and the $\mathrm{J}_{\mathrm{z}}$ value for the tested engine type. Based on the graph curves co-position, the $\mathrm{J}_{\mathrm{z}}$ value is changed until the course lines are equal at the speed of the catalogue maximum torque value. Then the effective torque course and calculated power course that is close to actual one could be obtained.

The courses obtained in that way can be used as basic courses for engine parameter comparison process.

\subsection{Comparative analysis}

The revving up test of the engine is conducted after the execution of the planned changes, control unit adjustment or the replacement of the elements of the fuelling system. Very important is that the engine mechanical configuration shouldn't be changed. For example the alternator exchange may result in the equivalent mass moment value change and then basic course should be re-determined.

Speed characteristics obtained as a result of the revvingup test are compared to the basic one and percentage changes of the engine torque and power are determined with the use of formula (5).

Effectiveness assessment of the change realized to the engine adjustment is performed on the basis of the relative change of operating parameters. Parameter change is determined with formula,

$$
\Delta \mathrm{w}_{\mathrm{i}}=\frac{\mathrm{w}_{\mathrm{ix}}-\mathrm{w}_{\mathrm{i}}}{\mathrm{w}_{\mathrm{i}}} \cdot 100 \%
$$

where: $\mathrm{w}_{\mathrm{ix}}$ - parameter value after the change is implemented, $\mathrm{W}_{\mathrm{i}}$ - parameter value before the change is implemented.

The effect of introduced changes could be observed with the use of adequate computer software which is based on a spread sheet. Graphic interpretation of the test results could be displayed on the monitor as curves $\Delta N_{e}=f(n)$. This could terystyki prędkościowej. Wyznaczenie przebiegu momentu obrotowego i mocy silnika wymaga przeliczenia wartości przyspieszenia kątowego według zależności (3) i (4),

gdzie: $\mathrm{T}_{\mathrm{e}}$ - efektywny moment obrotowy silnika $\mathrm{w} \mathrm{N} \cdot \mathrm{m}, \mathrm{N}_{\mathrm{e}}$ - moc efektywna silnika $\mathrm{w} \mathrm{kW}, \mathrm{J}_{\mathrm{z}}$ - zastępczy masowy moment bezwładności w $\mathrm{kgm}^{2}, \varepsilon$ - przyspieszenie kątowe wału korbowego w $1 / \mathrm{s}^{2}, \mathrm{n}$ - prędkość obrotowa w obr/min.

Po dokonaniu tych przeliczeń możliwe jest wykreślanie charakterystyk prędkościowych mocy i momentu obrotowego silnika, uzyskiwanych w warunkach nieustalonych pracy.

Podstawiając odpowiednio wartości do zależności (5), można analizować skuteczność wprowadzanych zmian.

\subsection{Wyznaczenie charakterystyki bazowej}

Wzory (3) i (4) wskazują, że podstawowe znaczenie dla obliczenia wartości momentu obrotowego i mocy ma wartość zastępczego masowego momentu bezwładności $\mathrm{J}_{\mathrm{z}}$. Za pomocą tego parametru można w praktyce uzyskiwać różne wartości momentu obrotowego i mocy dla tej samej wartości zmierzonego przyspieszenia kątowego.

Na wykresie $\mathrm{T}-\mathrm{n}$ nanosi się przebieg $\mathrm{T}_{\mathrm{e}}=\mathrm{f}(\mathrm{n})$ uzyskany ze źródła pewnego, na przykład z danych katalogowych danego silnika. Następnie nanosi się przebieg momentu $\mathrm{T}_{\mathrm{e}}{ }^{\varepsilon}=\mathrm{f}(\mathrm{n})$ obliczony na podstawie zmierzonych wartości przyspieszeń kątowych i wartości J dla danego typu silnika. Obserwując wzajemne położenie linii przebiegów, zmienia się wartość $\mathrm{J}_{\mathrm{z}}$, tak aby wartości linii przebiegów pokrywały się dla prędkości obrotowej katalogowego momentu maksymalnego silnika. Wtedy uzyska się przebieg momentu efektywnego i wyliczony na jego podstawie przebieg mocy, zbliżony do rzeczywistego.

Uzyskane w ten sposób przebiegi mogą być uznane za przebiegi bazowe do porównywania parametrów silnika.

\subsection{Analiza porównawcza}

Po dokonaniu planowanej zmiany, regulacji nastaw urządzeń sterujących czy wymianie elementów układu zasilania, wykonuje się test rozpędzania silnika. Należy zwrócić uwagę na to, aby nie zmieniła się konfiguracja silnika pod względem mechanicznym. Na przykład wymiana alternatora może spowodować zmianę wartości zredukowanego momentu bezwładności i wtedy należy powtórnie określić charakterystykę bazową.

Uzyskane w wyniku testu rozpędzania charakterystyki prędkościowej porównuje się z charakterystyką bazową, wyznaczając zmiany procentowe momentu obrotowego i mocy silnika przy wykorzystaniu wzoru (5).

Ocena skuteczności wprowadzonej zmiany w regulacji silnika dokonywana jest na podstawie względnej zmiany analizowanego parametru roboczego. Zmiana parametru wyznaczana jest według zależności (5),

gdzie: $\mathrm{w}_{\mathrm{ix}}$ - wartość parametru po zastosowaniu wprowadzanej poprawki, $\mathrm{w}_{\mathrm{i}}$ - wartość parametru początkowa, przed zastosowaniem wprowadzanej poprawki.

Dysponując odpowiednim oprogramowaniem komputerowym, opartym np. na arkuszu kalkulacyjnym, można obserwować na bieżąco skutki wprowadzanych zmian. Interpretacja graficzna wyników testu w postaci krzywych 
facilitate the determination of change trends of the engine operating parameters that are caused by the introduced modifications.

\section{Sample test results}

Sample speed characteristics of the engine torque that are measured during the revving-up test are presented in Fig. 1 and 2 . They are compared to the catalogue ones.

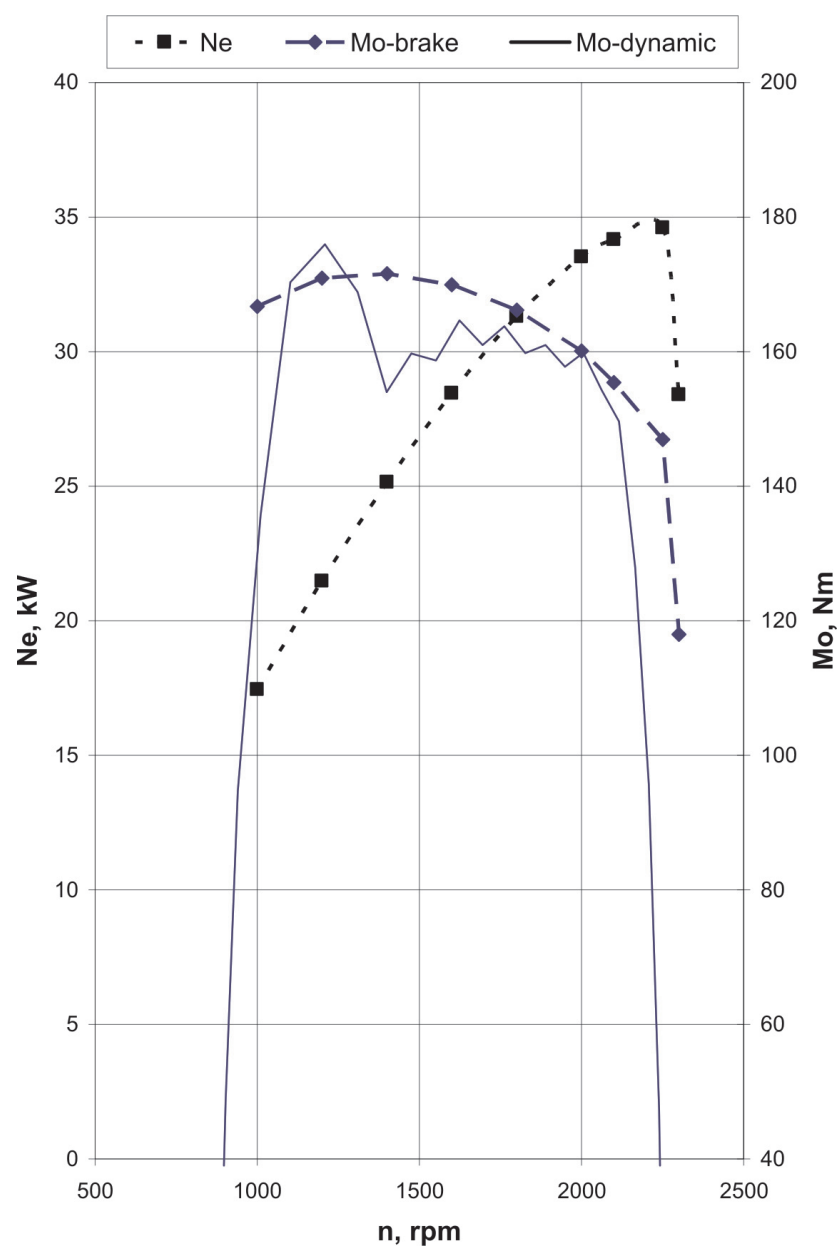

Fig. 1. AD3152 engine torque curve measured during the revving-up test and shown against the background of catalogue characteristics

Rys. 1. Zmierzona w teście rozpędzania krzywa momentu obrotowego silnika AD3.152 na tle charakterystyki katalogowej

Engine torque curves have been calculated by formula (4) on the base of the revving-up test results and actual values of the equivalent mass moment of engine inertia. The values of $\mathrm{J}_{\mathrm{z}}$ have been determined by a double retardation method [2]. It is shown that the parameter values obtained in the revving-up test do not exceed the ones obtained under the steady state conditions.

Angular acceleration values of AD3.152UR engine crankshaft obtained during the revving-up test are presented in Fig. 3. This is an example of modification introduced without the change of the engine mechanical configuration. The presented modification relied on the fuel state change caused by the magnetization process [3]. The results along
$\Delta \mathrm{N}_{\mathrm{e}}=\mathrm{f}(\mathrm{n})$, wyświetlana na monitorze, ułatwi określenie tendencji zmian parametrów roboczych silnika spowodowanych wprowadzonymi modyfikacjami.

\section{Przykładowe wyniki testów}

Przykładowe charakterystyki prędkościowe momentu obrotowego, zmierzone $\mathrm{w}$ teście rozpędzania i porównane $\mathrm{z}$ charakterystykami katalogowymi przedstawiono na rys. 1 i 2 .

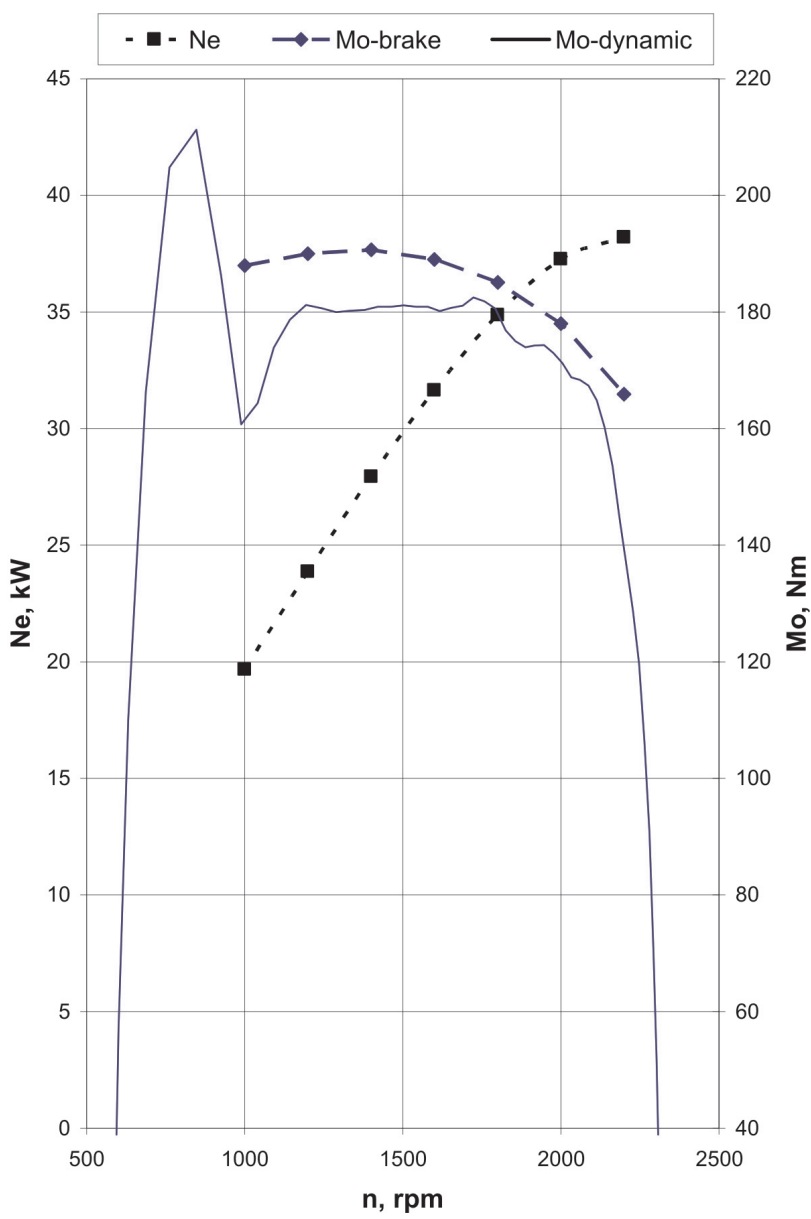

Fig. 2. S-4003 engine torque curve measured during the revving-up test and shown against the background of catalogue characteristics

Rys. 2. Zmierzona $w$ teście rozpędzania krzywa momentu obrotowego silnika S-4003 na tle charakterystyki katalogowej

Krzywe momentu obrotowego obliczono według zależności (4) na podstawie wyników testu rozpędzania i znanych wartości zredukowanego masowego momentu bezwładności. Wartości Jz wyznaczono metodą podwójnego wybiegu [2]. Widoczne jest, że wartości parametru wyznaczonego w teście rozpędzania nie przekraczają wartości uzyskanych w ustalonych warunkach pracy.

Na rysunku 3 przedstawiono wartości przyspieszenia kątowego wału korbowego silnika AD3.152UR uzyskane w teście rozpędzania. Jest to przykład wprowadzania modyfikacji bez zmiany konfiguracji mechanicznej silnika. Przedstawiona tu modyfikacja polegała na ingerencji w stan paliwa przez zastosowanie magnetyzowania paliwa [3]. Wyniki badań w postaci zmian procentowych dwóch 
the percentage change of two parameters - crankshaft angular acceleration and engine power - are shown in Fig. 4. The percentage changes of both parameters are identical which is illustrated by the coincided graph curves.

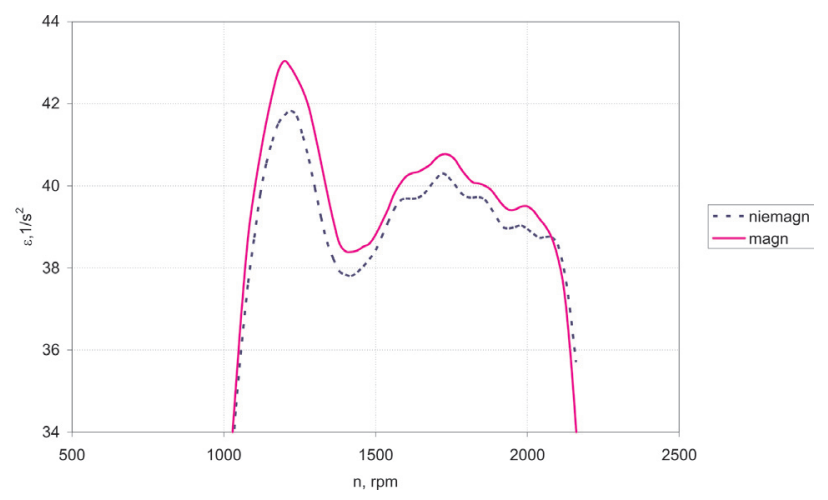

Fig. 3. Crankshaft angular acceleration values of AD3.152UR engine for magnetized diesel fuel that are measured during the revving-up test

Rys. 3. Zmierzone $w$ teście rozpędzania wartości przyspieszenia kątowego watu silnika AD3.152UR dla oleju napędowego poddanego magnetyzacji

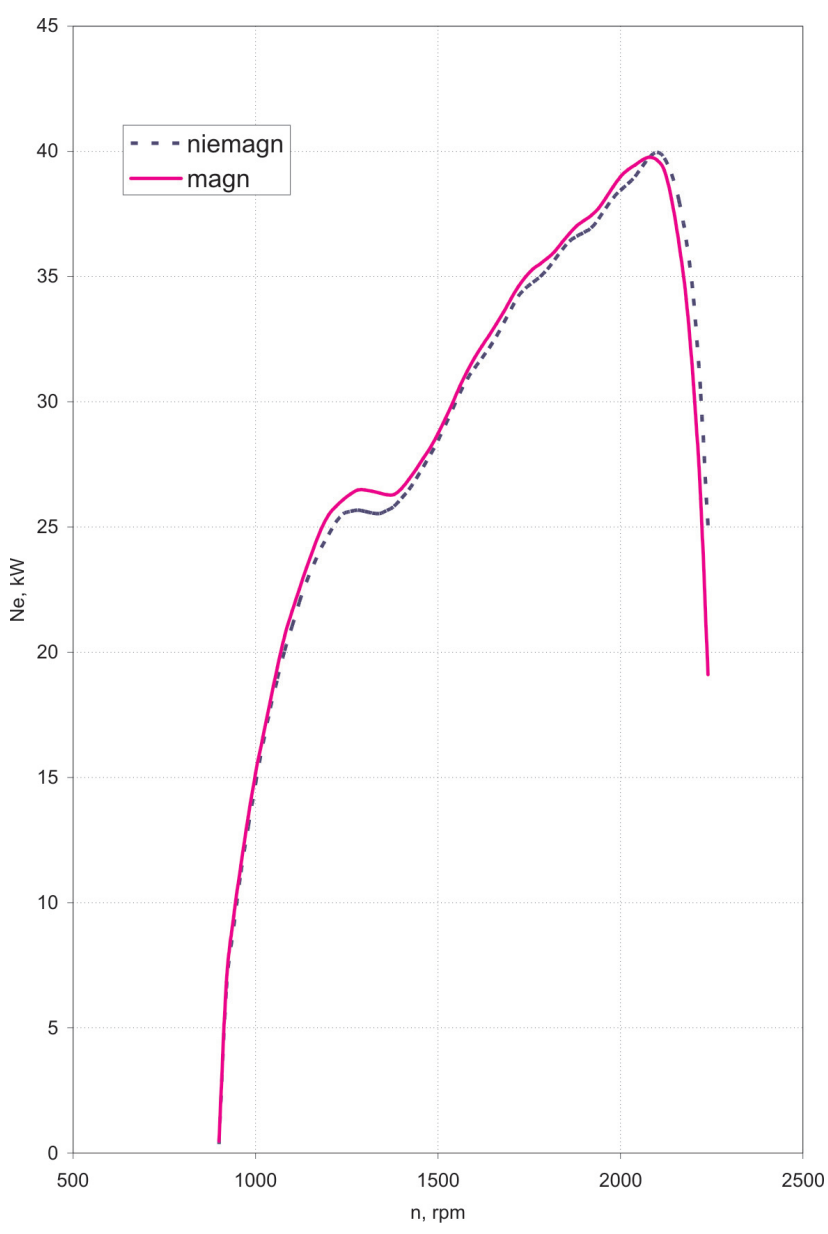

Fig. 5. Enlarged part of AD3.152UR engine characteristics for magnetized diesel fuel, power values are calculated with formula (4)

Rys. 5. Powiększony fragment charakterystyki silnika AD3.152UR dla oleju napędowego poddanego magnetyzacji, wartości mocy obliczono na podstawie wzoru (4) parametrów: przyspieszenia kątowego wału i mocy silnika przedstawiono na rys. 4. Jak widać, procentowe zmiany obu parametrów są identyczne, co ilustrują pokrywające się linie wykresów.

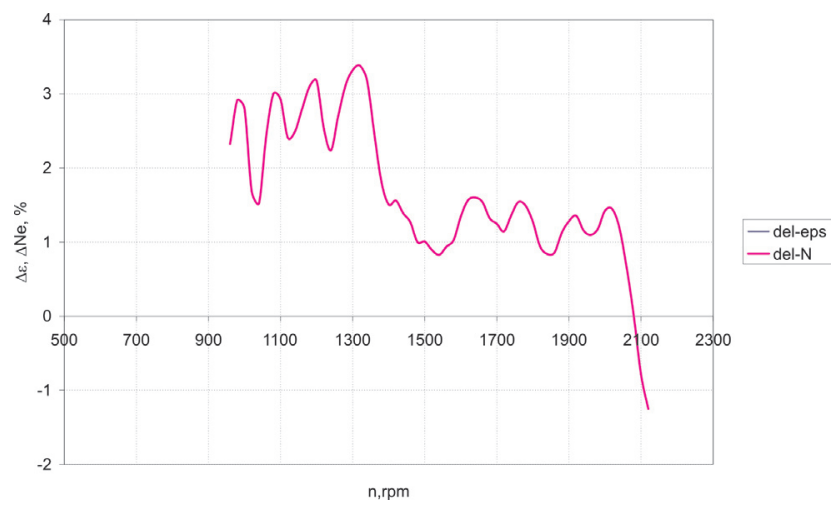

Fig. 4. Percentage changes of crankshaft angular acceleration and power of AD3.152UR engine for magnetized diesel fuel (graph curves are coincided)

Rys. 4. Zmiany procentowe wartości przyspieszenia kątowego watu $i$ mocy silnika AD3.152UR dla oleju napędowego poddanego magnetyzacji (wykresy się pokrywaja)

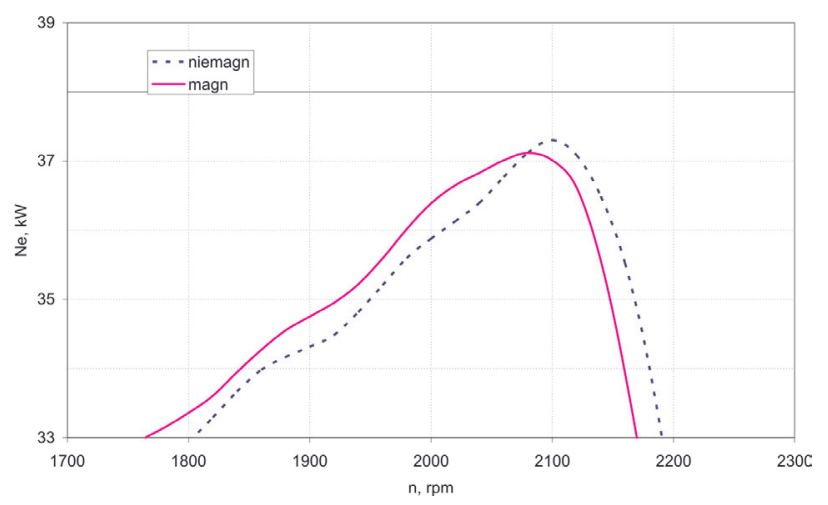

Fig. 6. Graphic illustration of AD3.152UR engine power changes under transient conditions for magnetized diesel fuel

Rys. 6. Ilustracja graficzna zmian mocy silnika AD3.152UR w warunkach nieustalonych dla oleju napędowego poddanego magnetyzacji

Analiza procentowych zmian wartości parametrów roboczych wskazuje na skuteczności wprowadzanych modyfikacji. W prezentowanym przypadku można stwierdzić, że magnetyzacja paliwa poprawia możliwości robocze silnika o około $2 \%$.

Prędkościowe charakterystyki mocy silnika, tzw. charakterystyki dynamiczne, mogą być wykorzystane do ilustracji uzyskanych wyników pomiarów. Na rysunku 5 przedstawiono powiększony fragment charakterystyki, który może być użyty do dokładniejszych porównań. Natomiast na rys. 6 przedstawiono pełną charakterystykę mocy, którą można wykorzystywać do ilustracji wyników pomiarów.

Należy podkreślić, że w przypadku dysponowania znaną wartością zredukowanego masowego momentu bezwładności silnika (dla konfiguracji silnika podczas testu), 
The analysis of the percentage changes of operating parameter values results in a conclusion as to the effect of the introduced modifications. In the presented case it can be stated that the fuel magnetization increases engine operating possibilities within the range of about $2 \%$.

Speed characteristics of engine power, the so-called dynamic characteristics, could be used for the illustration of the obtained test results. The enlarged part of the characteristics presented in Fig. 5 could be used for more exact comparison. However in Fig. 6 a full characteristic is presented that could be used for the illustration of the test results.

It should be emphasized that the graph in Fig. 6 shows the actual values of engine operating parameters under transient conditions when the true value of equivalent mass moment of inertia is known. It should of course be the value for engine configuration used in the test. However when the exact value of mass moment $\mathrm{J}_{\mathrm{z}}$ is unknown then graphic illustration of the engine parameters will be approached with respect to actual values.

\section{Conclusions}

Based on the simulation research results analysis it possible to state that:

1. The presented method of engine operating parameter determination enables the first assessment of the modification of the engine adjustments and changes that do not influence the basic engine structure.

2 . The result assessment of the introduced adjustment changes is based on the relative changes of the parameter that is measured with sufficient accuracy.

3 . The values of the determined operating parameters could be used for the illustration of the engine outputs as exact or approximated values because they correspond with the producer data.

4. The presented research method should be completed with engine equivalent mass moment determination technique which could increase the accuracy of the running measurements of the engine operating parameters during the revving-up.

Mr Zbigniew Kiernicki, PhD, MEng - doctor in Automotive Vehicles Department at Mechanical Faculty of Lublin University of Technology.

Dr inż. Zbigniew Kiernicki - adiunkt w Katedrze Pojazdów Samochodowych na Wydziale Mechanicznym Politechniki Lubelskiej. wykres na rys. 6 przedstawiać będzie rzeczywiste wartości parametrów roboczych silnika w warunkach rozpędzania. Natomiast, gdy nieznana jest dokładna wartość masowego momentu bezwładności silnika, ilustracja graficzna parametrów silnika będzie jedynie przybliżona do wartości rzeczywistych.

\section{Podsumowanie}

Analiza wyników badań symulacyjnych pozwala na sformułowanie następujących wniosków:

1.Proponowana metoda określania parametrów roboczych silnika umożliwia bieżącą wstępną ocenę modyfikacji nastaw i zmian nieingerujących w podstawową strukturę silnika.

2. Ocena skutków wprowadzanych zmian regulacyjnych oparta jest na względnych zmianach parametru mierzonego z wystarczającą dokładnością.

3. Wartości wyznaczonych parametrów roboczych mogą być wykorzystywane do ilustrowania osiągów silnika w sposób dokładny lub przybliżony, gdyż są w zasadzie zgodne z danymi producenta.

4. Przedstawiona metodyka powinna być uzupełniona o sposób wyznaczania zredukowanego momentu bezwładności silnika, co umożliwiłoby zwiększenie dokładności bieżących pomiarów parametrów roboczych silnika podczas rozpędzania.

\section{Artykut recenzowany}

\section{Bibliography/Literatura}

[1] Bernhardt M., Dobrzyński S., Loth E.: Silniki samochodowe. WKi屯, Warszawa 1988.

[2] Kiernicki Z.: Określanie masowego momentu bezwładności silnika spalinowego za pomocą cyklu rozpędzanie-wybieg. Czasopismo Techniczne, z. 5-M/1998 (rok 95).

[3] Kiernicki Z.: Effect of the magnetization of rape biofuel on DI diesel outputs under transient conditions. $5^{\text {th }}$ International Colloquium „Fuels 2005”, Esslingen-Stuttgart 2005

[4] Kiernicki Z.: The accuracy of engine crankshaft's speed and acceleration measurements in the inertial method of engine testing. Teka Komisji Motoryzacji i Energetyki Rolnictwa PAN, vol. II, Lublin 2002, 